\title{
Ubenimex の感染予防効果の研究
}

\section{一白血球減少マウスに括ける緑膿菌性腎盂腎炎での検討一}

\author{
札幌医科大学泌求器科教室 (主任: 熊本悦明教授) \\ 田仲 紀明熊本 悦明広瀬 崇興 横尾 彰文
}

(平成 1 年 2 月 6 日受付)

(平成 1 年 5 月 8 日受理)

Key wards : cyclophosphamide, neutropenic mice, Pseudomonas aeruginosa experimental pyelonephritis, Ubenimex

\section{要 旨}

Cyclophosphamide の 2 回投与により感染日から感染 7 日目の屠殺日まで, 末梢白血球数を $2,000 /$ $\mathrm{mm}^{3}$ 前後の減少状態に保たせたマウス実験モデルを作成した。そのマウスに対し, 緑膿菌（G 群）によ る上行性尿路感染実験を行い, 免疫調整物質である Ubenimex の細菌感染予防効果について検討した。

Cyclophosphamide 群は正常対照群に比し, 有意に易感染性化した。この cyclophospmide 群に Ubenimex $100 \mu \mathrm{g} / \mathrm{mouse}$ ，5 日間連日の予防投与を行った群では, Cyclophosphamide 単独群に比し尿 と腎の感染率扔よび感染死亡率は変らなかったが, 感染発症率が有意に低值となり, 感染予防効果を認 めた.

Ubenimex の予防投与を行っても末梢白血球数は感染日から感染 7 日後の屠殺日までの間, cyclophosphamide 単独群と比し, 増加を認めず白血球分画にも変動を認めなかった。 しかし腹腔浸出好中球 の領食殺菌能を検討すると, cyclophosphamide 単独群では正常対照群より著明低下したが, Ubenimex の予防投与に上り有意に促進を認めた。 以上の結果から, Ubenimexは自血球減少マウスに颃いて細菌 感染予防効果を有し，その作用機序の一つとして好中球の貪食殺菌能の促進に基ずくことが考えられた。

\section{序文}

癌化学療法による副作用の一つに骨髄抑制が挙 げられ，その結果宿主の感染防御能は低下する。 これらの宿主は易感染性であり日和見感染が発症 しやすく, かつ一旦発症すると難治化, 重症化し やすい1). その原因として，特に顆粒球や Macrophage などの貪食細胞数の減少および機能低下が 考兄られており2)，これらの宿主に対する治療対 策として貪食細胞数の増加やその機能の促進が期 待される。

その様な観点から, 我々は cyclophosphamide 投与により白血球を減少させたマウスの緑膿菌性

別刷請求先：（宁060）札幌市中央区南 1 条西16丁目 札幌医科大学泌尿器科学教室 田仲 紀明
上行性腎孟腎炎におけるヒト Granulocytecolony stimulating factor (G-CSF) の感染予防 和よび治療効果について報告した ${ }^{3)}$. その結果, G-CSF 予防投与群では有意な感染予防効果を示 したが, G-CSF 治療投与群ではその治療効果は認 めなかった。 そして予防投与群での感染予防効果 の機序は末梢好中球数の増加と好中球の貪食殺菌 能の促進の両者にもとずくものと考えられた。そ こで今回は同じ実験系を用いて既に臨床応用がさ れている免疫調整物質の Ubenimex の感染予防 効果を検討したので報告する。

\section{実験材料および方法}

\section{1. 実験動物}

6 週齢 $\mathrm{ddY}$ 系雌マウス（体重22２4g）を使用し た。 
2. 白血球減少マウスの作成法

Cyclophosphamideの 2 回投与を行った。 Cyclophosphamide (シオノギ製薬) を生理食塩水 に溶解し, $250 \mathrm{mg} / \mathrm{kg}$ の量をマウス背部に皮下注, 更にその 6 日後に $100 \mathrm{mg} / \mathrm{kg}$ を追加した。末梢白 血球数は心臓採血の後 EDTA 入り試験管に入れ 自動血球測定装置（東亜医用電子製 Sysmex ${ }^{\circledR}$ CC108）を用いて測定した。

\section{3. 使用菌株}

尿路感染症患者より分離されたPseudomonas aeruginosa ( $\mathrm{G}$ 群)を tripto-soy broth (栄研化学) に接種, $37^{\circ} \mathrm{C} 18$ 時間静置培養し，ムコイドを除去 した後, 生理食塩水にて菌数を $2 \times 10^{4} \mathrm{cells} / \mathrm{ml}$ に 調整した。

\section{4. .上行性尿路感染症の作成}

1 回目の cyclophosphamide 投与の 4 日後に, 以前報告した方法 ${ }^{4)}$ にり行った. 即ち, ネンブ タール麻酔下にマウスの外尿道口をアルコール綿 で清拭し, 経尿道的に菌液 $0.05 \mathrm{ml}$ をポリエチレン チューブを使用して膀脱内に注入した。注入後尿 道を 2 時間クランプして排尿による排菌を防止し た。

\section{Ubenimex 投与法}

Ubenimex は日本化薬（株）で製造された原末 （Bestatin ${ }^{\circledR}$, Lot NO. Y60001）を使用した。 Ubenimex は生理食塩水に溶解後, $0.45 \mu$ のミリ ポアフィルターで濾過した。投与法は Fig. 1 の如 く cyclophosphamide の投与開始と同時に100 $\mu \mathrm{g} / \mathrm{mouse}(0.2 \mathrm{ml} / \mathrm{mouse})$ を感染日まで 5 日間, 連日同一時刻に腹腔内へ投与する予防投与とし た.

\section{6. 尿中細菌数と腎内細菌数の定量}

感染 7 日後にマウスを屠殺する際, 麻酔下に膀 胱を露出し注射器で尿を採取した後, 膀脱を摘出 した。尿は希釈後 NAC (栄研化学) 寒天平板培地 で菌数定量した。次に両腎を摘出し, 左右腎を各々 半切した. 各左右半切腎を homoginate し, 希釈後 同様に菌数定量した。

腎と尿の感染率（\%）は,

$$
\frac{\text { 感染死亡数 }+ \text { 感染個体数 }}{\text { 全個体数 }} \times 100
$$

とした，有意差検定は $\mathrm{X}^{2}$ 検定を用いた。

\section{7. 組織学的検討}

摘出した膀胱と残りの左右半切腎を $10 \%$ 中性緩 衝ホルマリン固定後, パラフィン包埋し, 切片に hematoxylin-eosin (H-E) 染色を施行し, 光学顕 微鏡にて観察した。

膀胱炎の程度は粘膜下の好中球浸潤と浮腫の程

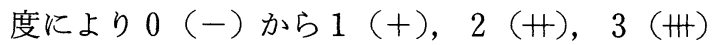
までの 4 段階で評価した。

腎孟腎炎の程度も 4 段階で評価し，0度 (一) は炎症 (好中球浸潤) なし，1度（十）は炎症が 腎孟内にとどまるもの，2 度（サ）は炎症が髄質 内及び軽度に皮質に波及するもの，3 度（卅）は 肉眼的組織学的に被膜下膿瘍を形成したものとし た。腎の組織変化の程度は左右の腎の平均值で表 した。有意差検定は $\mathrm{X}^{2}$ 検定を用いた。

8. 好中球の貪食殺菌能の検討

a) 好中球浮遊液の作成

好中球の分離は $5 \%$ カゼイン生食 $(\mathrm{pH} 7.4) 1 \mathrm{ml}$ をマウス腹腔内に注入し， 6 時間後に腹腔内に浸 出した好中球をへパリン含有 Hanks 液で腹腔内

Fig. 1 Administration schedule of cyclophosphamide and Ubenimex

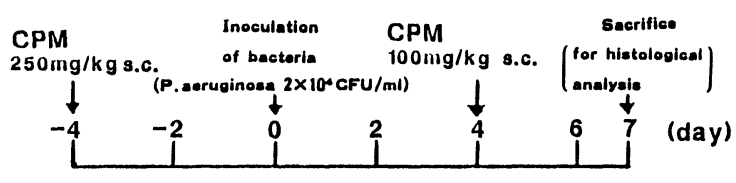

CPM group

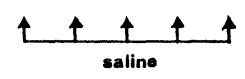

CPM+Ubenimex group $\downarrow \uparrow \uparrow \uparrow \uparrow$

Ubenimex $100 \mu \mathrm{g} /$ mouse I.o. 
洗浄することによって得た。これを $4{ }^{\circ} \mathrm{C} 1,500$ 回転 20分間の遠沈により 2 回洗浄後, Hanks 液にて好 中球浮遊液を作成し, 細胞数を $2 \times 10^{6} \mathrm{cells} / \mathrm{ml}$ に Thoma 型計算板にて調整した。好中球浮遊液の 塗洙標本は Giemsa 染色にて $90 \%$ 以上が好中球で あった。

b）正常マウス血清の作成

細菌のオプソニン化のためのマウス血清は，10 匹のマウスから心臓採血し血清分離後, $-80^{\circ} \mathrm{C}$ に 保存した。使用時溶解し $20 \%$ に希釈して使用した。

c）貪食殺菌能の検討

Quie の方法 ${ }^{5}$ に準じ，P. aeruginosa（G 群）菌 液 $\left(1 \times 10^{7}\right.$ cells $\left./ \mathrm{ml}\right) 0.1 \mathrm{ml}$ と好中球浮遊液 $(2 \times$ $\left.10^{6} \mathrm{cells} / \mathrm{ml}\right) 0.5 \mathrm{ml}$ とマウス希釈血清 $0.4 \mathrm{ml}$ Falcon tube（No. 2054）に入れ，最終液量 $1 \mathrm{ml}$ と し $37^{\circ} \mathrm{C}$ で震盪培養を行った. 反応 60 分と 120 分後に $0.1 \mathrm{ml}$ を取り, $5 \mathrm{ml}$ の蒸留水に加え激しく混和し て好中球を破壊し，10倍段階希釈後に NAC 寒天 平板培地を用いて残存生菌数を測定した。好中球 の貪食殺菌率（\%）は以下のように計算した。

$$
\frac{\text { 添加菌数 }- \text { 残存菌数 }}{\text { 添加菌数 }} \times 100
$$

有意差検定は $\mathrm{t}$ 検定を用いた。

\section{成 績}

1. Cyclophosphamide 投与による末梢白血球 数の推移 (Fig. 2)

前回報告したよう ( $^{3)}$, 投与前の白血球数は 6,660 $5594 / \mathrm{mm}^{3}$ であるが 1 回目の Cyclophosphamide 投与により 4 日後には $1,780 \pm 420 / \mathrm{mm}^{3}$ まで低下した。しかし 1 回投与のみでは，その後 直ちに白血球数は回復し, 8 日後では $5,960 \pm 385 /$ $\mathrm{mm}^{3}$ と処置前值に戻った。 そこで 1 回目の投与日 から 6 日後に 2 回目の cyclophosphamide 投与を 行った。この方法により更にその 6 日後でも $2,140 \pm 397 / \mathrm{mm}^{3}$ に白血球減少状態を維持する事 が可能であった。

2. 膀胼尿中および腎内細菌数 (Fig. 3, 4)

感染 7 日後の膀胱尿の細菌感染率は, 正常対照 群では27\%であったが cyclophosphamide 単独群 では $59 \%$ と有意に高值であった。 Ubenimex 予防 投与群では $48 \%$ cyclophosphamide 単独群に比 し低值であったが有意差は認めなかった。

次に腎内細菌数の検討では, 正常対照群の感染 率27\%に比し, cyclophosphamide 単独群では $57 \%$ と有意に高值であった。 Ubenimex 予防投与 群では $48 \%$ cyclophosphamide 単独群に比し低 値であったが有意差は認めなかった。

Fig. 2 Effect of cyclophosphamide on total number of white blood cells $\bigcirc-\boldsymbol{\Delta}$ : single injection of cyclophosphamide, $\bigcirc-$ : double injection of cyclophosphamide

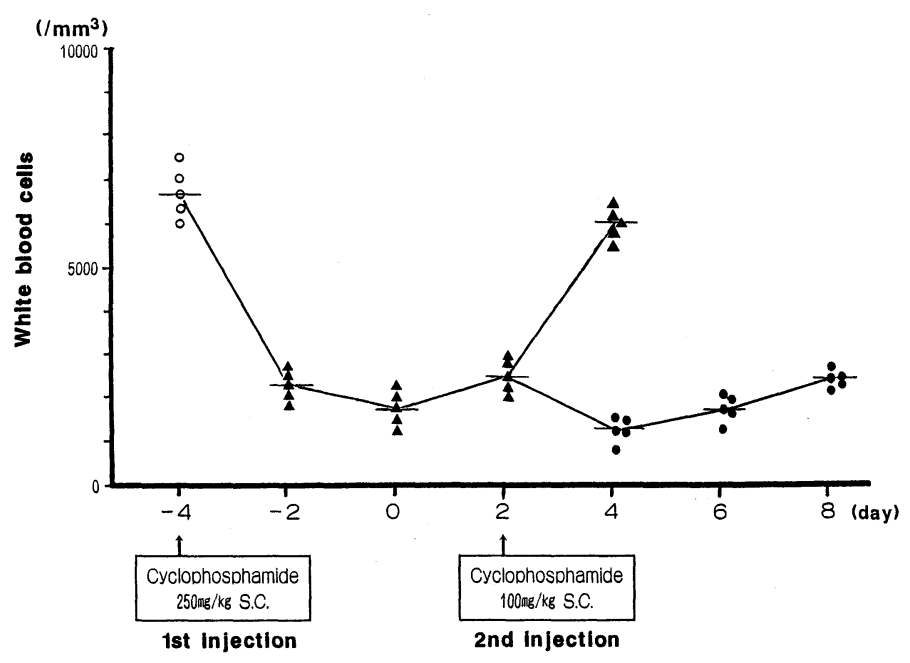


Fig. 3 Number of bacterla $/ \mathrm{ml}$ urine of bladder after 7 days of inoculation of $P$. aeruginosa $\left(2 \times 10^{4} \mathrm{CFU} / \mathrm{ml} \times 0.05 \mathrm{ml}\right)$

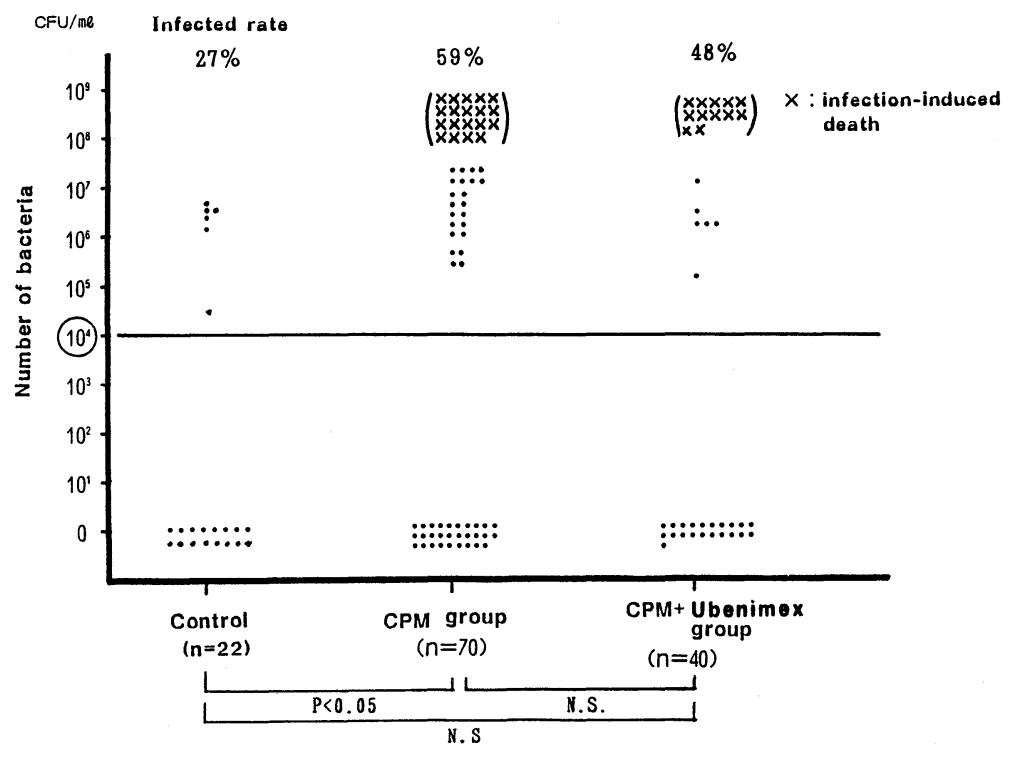

Fig. 4 Number of bacteria/g tissues of kidney after 7days of inoculation of $P$. aeruginosa $\left(2 \times 10^{4} \mathrm{CFU} / \mathrm{ml} \times 0.05 \mathrm{ml}\right)$

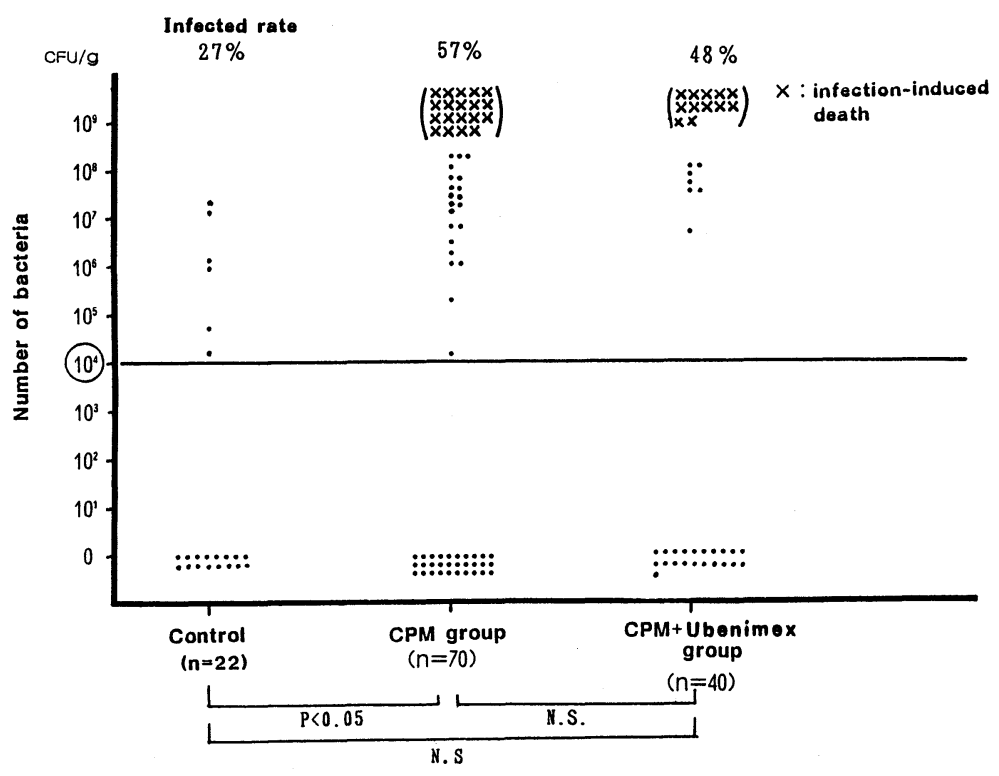

3. 膀胱組織の炎症性変化（Fig. 5)

感染 7 日後の感染発症率は, 正常対照群では $68 \%$ ぞその程度も軽度であったが, cyclophosphamide 単独群では96\%であり有意に強い炎症
変化を認めた. Ubenimex 予防投与群では $87 \%$ の 感染発症率で cyclophosphamide 単独群より若干 低值であった。

4. 腎組織の炎症性変化（Fig. 6) 
Fig. 5 Histological grade of cystitis after 7days inoculation of $P$. aeruginosa $\left(2 \times 10^{4} \mathrm{CFU} / \mathrm{ml} \times 0.05 \mathrm{ml}\right)$

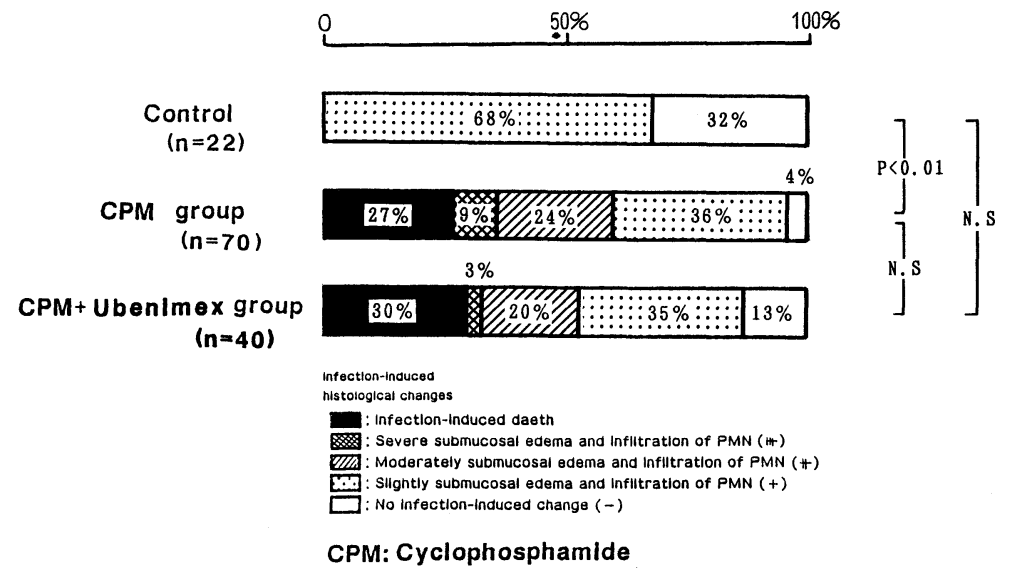

Fig. 6 Histological grade of pyelonephritis after 7days of inoculation of P. aeruginosa $\left(2 \times 10^{4} \mathrm{CFU} / \mathrm{ml} \times 0.05 \mathrm{ml}\right)$



正常対照群では感染死亡はなく感染発症率は 34\%と低值であった. Cyclophosphamide 単独群 では $27 \%$ が死亡，27\%で膿瘍形成を認め，全体で $91 \%$ の感染発症率となり著明な易感染性化を認め た. Ubenimex 予防投与群では感染死亡率は30\% と cyclophosphamide 単独群と変らないが, 感染 発症率は全体で $72 \%$ と有意に低值となった。

5. Ubenimex 投与時の末梢白血球数と白血球 分画 (Fig. 7, 8)

Ubenimex 予防投与群での感染発症率の有意の 低下の理由を分析するため, Ubenimex 投与時の 末梢白血球数扣よびその分画を検討してみた。 そ
の検討用の採血はすべて Ubenimex 投与24時間 後に行った。細菌非注入時に括ける検討では, Ubenimex の予防投与によっても白血球数は感染 予定日 $\left(1,175 \pm 450 / \mathrm{mm}^{3}\right)$ から屠殺日 $(2,269 \pm$ $\left.380 / \mathrm{mm}^{3}\right)$ まで cyclophosphamide 単独群に比し 増加は認めず，その分画に拈いても有意の変動は 認めなかった。

6. 腹腔浸出好中球の貪食殺菌能 (Fig. 9)

このようにUbenimex投与により白血球数およ び分画には変化が認められないので, 白血球の機 能検査として好中球の貪食殺菌能へのUbenimex の作用を検討した。細菌との接触60分および 120 分 
Fig. 7 Effect of Ubenimex on the reduction of peripheral white blood cells in cyclophosphamide-treated mice

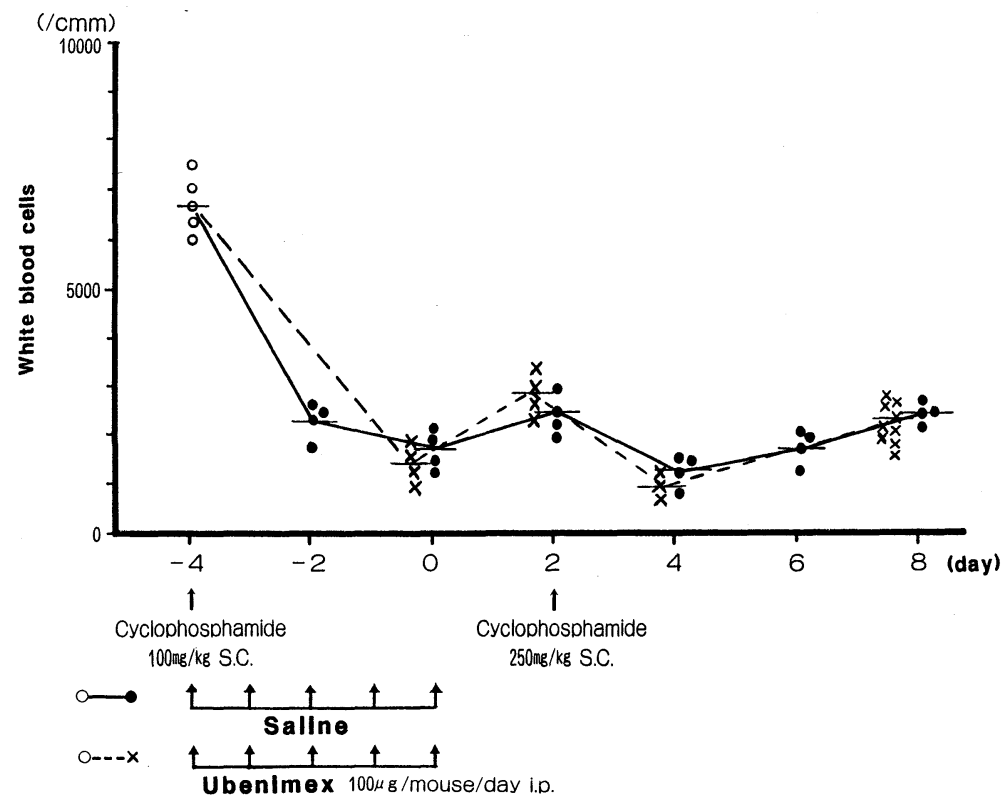

Fig. 8 Effect of Ubenimex in the differential white blood cells count in cyclophosphamide-treated mice

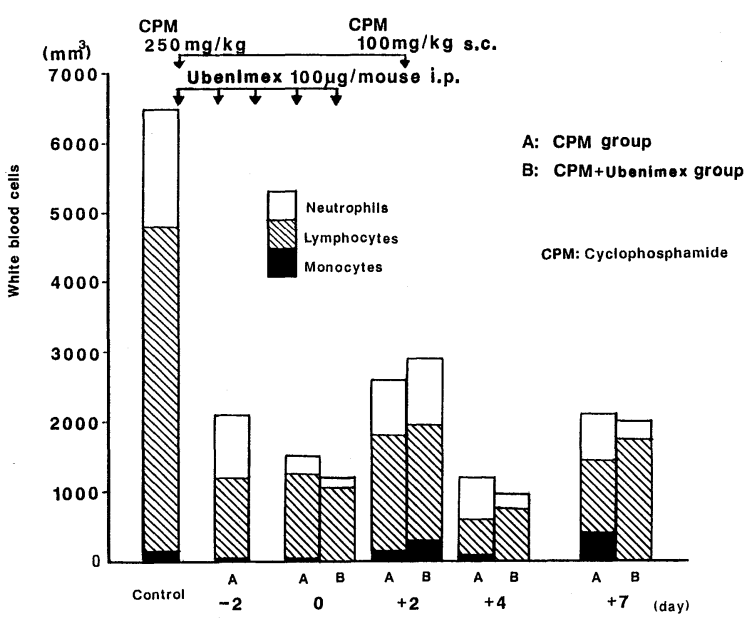

後の貪食殺菌率は, 正常対照群ではそれぞれ37\%, 63\%であった. Cyclophosphamide 投与 4 日後で は $0 \%$ ，14\%と有意に低下したが，これにUbenimex 4 日間連続投与した群では $32 \%$ ，34\%と著 明な貪食殺菌率の上昇を認めた。この所見から Ubenimex 投与群における感染発症率低下の背景
になると考えられる。

\section{考 案}

Ubenimex は二つのアミノ酸が結合した分子量 308の低分子の dipeptideであり，1975年梅沢が Streptomyces olivereticuli の培養濾液中に aminopeptitase B 阻害物質を発見し，命名したもの である ${ }^{6)}$. 本物質は免疫修飾作用を有するが，その 作用は免疫担当細胞の表面に存在する膜酵素であ る aminopeptitase B や Leucin-aminopeptitase と結合することによるとされている。

Ubenimex の持つ免疫反応には種々のものが知 られている7)819). 一つに Macrophage を活性化し て抗腫瘍活性を誘導し,さらに Macrophage の IL-1 産生を増強しリンパ球の分化, 増殖を促進す る. $\mathrm{T}$ 細胞に対しては遅延型過敏反応により GVH (移植片対宿主) 反応を増強し, また Helper T 細胞に作用して IL-2 の産生を増強する。その結 果 Killer $\mathrm{T}$ 細胞, $\mathrm{LAK}$ 細胞, $\mathrm{NK}$ 細胞などの Effector 細胞の分化，増殖を促進する。ささらには 骨髄の造血幹細胞に対して colony 形成を増強す る作用も認められている。これらの非特異的免疫 調節作用により各種の実験腫瘍に対する抗腫瘍作 
Fig. 9 Effect of Ubenimex on bactericidal capacity of peritoneal exudating neutrophils

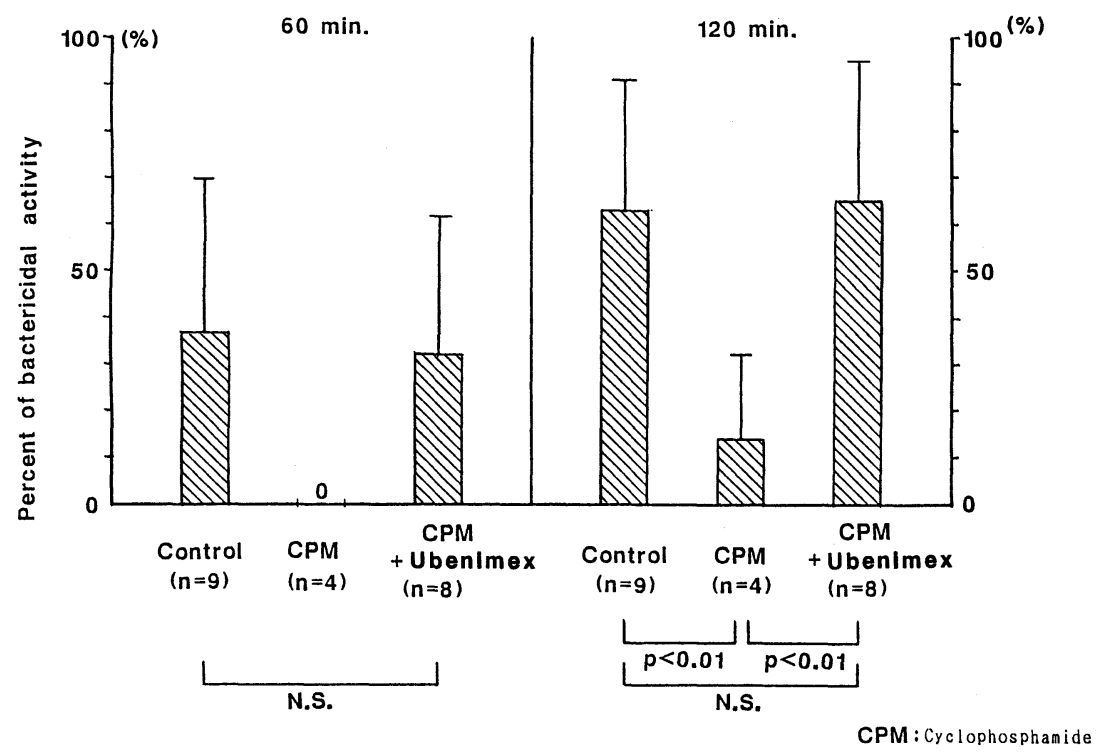

用が認められている。

細菌感染症に対する Ubenimex の効果は, 本物 質が Macrophage や T 細胞に作用し，種々のサ イトカインの産生を促進するため, 宿主の免疫機 能を修飾して感染防御作用を示するのと予想され る。これらのサイトカインの中で，まずIL-2 に関 しては Chongは実験的にマウスの静脈内あるい は腹腔内に致死量の大腸菌, 緑膿菌を感染させ, その $1-18$ 時間前に組換え型七ト IL-2を感染と 同じ経路で投与すると，70９0\%生残するとし， その作用は Macrophage の活性化によるものと している ${ }^{10)}$. た Ozaki らは, 組換え型ヒト IL$1 \alpha$ の投与によっても, 大腸菌, 肺炎桿菌のマウス 腹腔内感染による死亡率が減少されると報告して いる11).さらに CSF (colony stimulating factor) に関しては, Ubenimex の投与により骨髄の有核 細胞数の増加作用 ${ }^{12)}$, 顆粒球一Macrophage から なる colony の生成を促進する13)ことから Ubenimex による CSF の産生穴進が考兄られるが，こ れにより骨髄幹細胞活性の増強が起こり幹細胞の サイクルと数が増加されるものと考えられる.

また白血球機能に対する Ubenimex の作用は, in vitroの検討に敃いて Ubenimex をヒト顆粒球
と incubateすると, 顆粒球の貪食能 ${ }^{14)}$ ○ spontaneus migration，または化学的走化因子の存在


以上の理由により, Ubenimex は細菌感染予防お よび治療効果を示し得ると期待される。

細菌感染実験に打けるUbenimex の効果に関 しては大腸菌の経静脈感染モデルにおいて感染後 35日の時点で評価した腎の慢性感染において，対 照では67\%の感染率であったものが Ubenimex の予防および治療投与によりそれぞれ $0 \%, 14 \%$ と減少し, Ubenimexの予防, 治療効果を認めた としている(16). そしてこの場合の Ubenimex の作 用機序として, Macrophage の化学発光の増強か ら活性酸素の産生六進, また腹腔内に接種した Listeria monocytogenes の clearance の六進が みられることから Macrophage 活性の増強が考 えられるとしている。他にも Salmonella typhimurium, Listeria monocytogenes といった細胞内 寄生性細菌の肝, 脾に打ける慢性感染に打いて, Macrophage や $\mathrm{T}$ 細胞といった細胞性免疫能の 刺激作用によって Ubenimex の予防, 治療効果を 認めたとしている ${ }^{17)}$.

易感染性宿主に対する細菌感染実験では, 梅沢 
はマウスで cyclophosphamide $50 \mathrm{mg} / \mathrm{kg}$ 投与 4 日後に緑膿菌の腹腔内感染実験を行った ${ }^{18)}$ 。との 結果 Ubenimex $10 \mu \mathrm{g} /$ mouse の感染前 5 日間投 与により cyclophosphamide 単独群に比し感染 8 日後までの生残率の上昇を認めている。

我々の作成した易感染性の実験系は，cyclophosphamide 2 回投与によって血球数が $2,000 /$ $\mathrm{mm}^{3}$ 前後で好中球が $500 / \mathrm{mm}^{3}$ 前後とょり重篤に 減少させたマウスに対する急性の感染モデルであ る。このため Ubenimex の予防投与により，腎， 尿の感染率, 感染死亡率は cyclophosphamide 単 独群と有意の差を認めなかったが，感染発症率は 有意に低下し感染予防効果が認められた。

我々の検討では, cyclophosphamideにより末 梢白血球数が減少したマウスにUbenimexを予 防投与しても，先に報告した G-CSF 予防投与で 認めたよらな感染 7 日目までの白血球数の増加や 分画上の変動を認めなかった。しかし cyclophosphamide (300mg/kg 1 回投与)に誘発されたマウ スの骨髄抑制に対し Ubenimexを予防投与して 抢くことにより回復過程に打いて末梢白血球数, 骨髄有核細胞数の回復が促進されるとの報告があ る ${ }^{19)}$. 我々の実験では感染 7 日目では末梢白血球 はまだ回復していなかったものの，骨䯣中の細胞 数は増加していることが予想されるところである が，それが感染予防効果と結びつくか否かについ ては明らかではない。

しかし, Ubenimex 投与時の白血球機能を検討 すると腹腔浸出好中球の貪食殺菌能は有意に上昇 していた。この結果から我々が行った Ubenimex の白血球減少マウスに怙ける細菌感染予防効果の 作用機序としては好中球の貪食殺菌能の促進に基 ずくことが考えられた。また cyclophosphamide による易感染性化の機序として貪食細胞数の減少 以外に，抗体産生能や細胞性免疫能の抑制による ものも考えられる2). このため Ubenimex の免疫 調節作用によりその機能低下が改善されることは 当然想定されるところである。

以上のように白血球減少の易感染性宿主に抢け る Ubenimex の細菌感染予防効果が期待された。 抗癌剂投与による骨髄抑制からの回復をUbeni- mex の投与により促進することが期待され，また その際に発症しうる重篤な感染の発症率を軽減で きる可能性が示唆された。

\section{文献}

1）国井乙彦: Compromised host と感染症. 臨床と 研究. $63: 2124-2131$.

2）堀誠：免疫不全と感染．免疫と疾患，3：475 $-486,1982$.

3）田仲紀明, 熊本悦明, 広瀬崇興, 横尾彰文 : ヒト Granulocyte-colony stimulating factor (GCSF）の感染予防および治療効果の研究. 一白血 球減少マウスに拈ける緑膿菌性腎孟腎炎での検討 一. 感染症誌, $63:$ 145-155, 1989.

4）岡山 悟, 熊本悦明, 西尾 彰: 実験的膀胱炎の 感染発症機序に関する研究. 第 1 報. 細菌侵入経 過の分析. 日泌尿会誌, 75: 1380-1390, 1984.

5) Quie, P.G., White, J.G., Holmes, B. \& Good, R. A. : In vitro bacteriocidal capacity of human polymorphonuclear leukocytes: Diminished activity in chronic granulomatous disease of childhood. J. Clin. Invest., 46: 668-679, 1967.

6) Umezawa, H., Aoyagi, T., Suda, H., Hamada, M. and Takeuchi, T.: Bestatin, an inhibitor of aminopeptitase B, produced by actinomycetes. J. Antibiotics, 29 : 97-99, 1976.

7) Ishizuka, M., Aoyagi, T., Takeuchi, T. \& Umezawa, H.: Activity of Bestatin: Enhancement of immune responses and antitumor effect. Umezawa, H. (ed) Small Molecular Immunomodifiers of Microbial Origin. Japan Scientific Societies Press, Tokyo, p17-38, 1980.

8) Aoike, A., Tanaka, Y., Hosokawa, T., Yamaguchi, N. \& Kawai, E.: Effect of Bestatin on natural killer activity. Umezawa, $\mathrm{H}$. (ed) Small Molecular Immunomodifiers of Microbial Origin. Japan Scientific Societies Press, Tokyo. p101-107, 1980.

9) Shibuya, K.: Enhancement of interleukin 1 and interleukin 2 releases by ubenimex. J. Antibiotics, 40 : 363-369, 1987.

10) Chong, K.T.: Prophylactic administration of interleukin-2 protects mice from lethal challenge with gram-negative bacteria. Infect. Immun., 55 : 668-673, 1987.

11) Ozaki, Y., Ohashi, T., Minami, A. \& Nakamura, S.: Enhanced resistance to bacterial infection induced by recombinant human interleukin-1 $\alpha$. Infect. Immun., $55: 1436-1440$, 1987.

12) Kimura, I. : Effect of Bestatin on hematopoiesis. Cancer Treatment Reviews, 7 : 
257-260, 1980.

13) Maekawa, T.: Effect of Bestatin on human granulocyte-macrophage progenitor cells (CFU-C) in vitro and its possible mechanism of action. J. Kyoto Pref. Univ. Med., 93: 1039 $-1044,1984$.

14) Jarstrand, C. \& Blomgren, H. : Increased granulocyte phagocytosis after oral administration of Bestatin, a new immunomodulator. J. Clin. Lab. Immunol., 7 : 115-118, 1982.

15) Jarstrand, C. \& Blomgren, H.: Bestatin, a new immunomodulator, enhances migration and phagocytosis of human granulocytes in vitro. J. Clin. Lab. Immunol., 5 : 67-69, 1981.

16) Dickneite, G., Schoriemmer, H.U. \& Sedlacek, H.H. : Chronic bacterial infection models for
BRM screening. Behring lnst. Mitt. , $74: 174$ $-182,1984$.

17) Harada, Y., Kajiki, A., Higuchi, K., Ishibashi, T. \& Takamoto, M.: The model of immunopotentiating action of Bestatin. Enhanced resistance to Listeria monocytegenes infection. J. Antibiotics, 36 : 1411-1414.

18) Umezawa, H.: Screening of small molecular microbial products modulating immunoresponses and Bestatin. Recent Results Cancer Reseach, 75: 115-125, 1980.

19）内田耕三郎, 厚井文一, 依光聖一, 高橋 功, 喜 多嶋康一, 木村有郎 : Bestatin による cyclophosphamide 誘発骨髄抑制からの回復促進効果. 癌と 化学療法, 9: 220-224, 1982.

\section{Study of the Prophylactic Effect of Ubenimex on Experimental Pyelonephritis Induced by Pseudomonas aeruginosa in Neutropenic Mice

\author{
Noriaki TANAKA, Yoshiaki KUMAMOTO, Takaoki HIROSE \& Akifumi YOKOO \\ Department of Urology, Sapporo Medical College
} \\ (Director: Prof. Yoshiaki KUMAMOTO)}

We investigated the prophylactic effect of Ubenimex on mice with ascending pyelonephritis induced by Pseudomonas aeruginosa (G-group). This experimental model was established by a two course administration of cyclophosphamide, so that it kept the mice in a neutropenic status (around 2000 white blood cells $/ \mathrm{mm}^{3}$ ) from the time of infection to the time of sacrifice.

The cyclophosphamide-treated group increased their susceptibility more than the control group. In the cyclophosphamide-treated group, the prophylactic administration of Ubenimex $(100 \mu \mathrm{g} /$ day/mouse) did not produce significant decreases of infection-induced motality rate, but yielded a lower incidence of infection than of saline alone.

Administration of Ubenimex was not able to increase the number of neutrophils during the experiment. An investigation of the bactericidal capacity of peritoneal exudating neutrophils revealed that Ubenimex prophylactic administration accelerated its capacity, although cyclophosphamide alone did not.

These results suggest that Ubenimex has a prophylactic effect on bacterial infection in neutropenic mice, and that this effect, in part, depends upon the acceleration of bactericidal capacity of neutrophils produced by Ubenimex. 